\title{
Regional Government Cooperation in Keeping Brantas River Basin with Sumber Brantas Village Community, Bumiaji Sub-District, Batu City
}

\section{HODAIFAH $^{1}$, TRI SULISTYANINGSIH ${ }^{2}$, MASDUKI $^{2}$}

\author{
${ }^{1}$ Pemerhati DAS Brantas Jawa Timur \\ ${ }^{2}$ Universitas Muhammadiyah Malang \\ masduki66@gmail.com
}

\begin{abstract}
Awareness of Batu City residents to keep the Brantas River is still low, whereas Batu Regional Government has Regional Regulation (PERDA) No. 7 of 2011 on Spatial Planning for Year 2010-2030 and Regional Regulation No 16 Year 2011 on Protection, Conservation and Environmental Management. From the existing regulations should be enough to help the existence of forests that support the Brantas watershed, but the systematization of natural resource management is still not communicated well by the surrounding community. Lack of understandingand awareness in cooperation is a gap that makes the goal in protecting and preserving the Brantas River Basin did not materialize. The importance of growing mutual attitude among the community is needed to control the problems that occur in the Brantas River Basin. This raises the question for the researcher as stated in the formulation of the problem in this research, that is (1) How Local Government Action in effort to tackle BrantasWatershed? (2) How is the cooperation between the Regional Government and Sumber Brantas Village Communities in maintaining the Brantas River? (3) How is the social life of Sumber Brantas Village community in maintaining the Brantas waters hed? The type of research is descriptive qualitative research (Description Research). The research area was chosen purposively, in Sumber Brantas Village, Bumiaji District, Batu City. This study uses field notes and in-depth interviews of informants namely the Local Government and the Brantas River Basin community. The data obtained will be analyzed using qualitative descriptive technique and the data is checked for validity by triangulation. The findings of the research results, the cooperation between the Government and the Sumber Brantas Village Communities are still not optimal, because the community participation is still weak, this makes the problems that occurin the Brantas waters hed protracted
\end{abstract}

Received:April7,2018

Revised:April11,2018 Accepteed:April19,2018 
Vol. 1 No.1

March2018

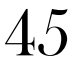

in handling. The village community of Sumber Brantas is categorized as a farmer community which is known to still be thick with work together, it can be seen in the daily life of the community as well as the capital to increase people's understanding of the importance of keeping the Brantas watershed together.

Keywords: Spatial Planning; Conservation and Environmental Management; Brantas watershed.

\section{ABSTRAK}

Kesadaran warga Kota Batu untuk menjaga agar Sungai Brantas tetap rendah, sedangkan Pemerintah Daerah Batu memiliki Peraturan Daerah (PERDA) Nomor 7 Tahun 2011 tentang Penataan Ruang untuk Tahun2010- 2030 dan Peraturan Daerah Nomor 16 Tahun 2011 tentang Perlindungan, Konservasi dan Lingkungan Hidup Pengelolaan. Dari peraturan yang ada seharusnya cukup untuk membantu keberadaan hutan yang mendukung DAS Brantas, namun sistematisasi pengelolaan sumber daya alam masih belum bisa dikomunikasikan dengan baik oleh masyarakat sekitar. Kurangnya pemahaman dan kesadaran kerja sama adalah celah yang membuat tujuan melindungi dan melestarikan DAS Brantas tidak terwujud. Pentingnya tumbuh sikap timbal balik di kalangan masyarakat diperlukan untuk mengendalikan permasalahan yang terjadi di DAS Brantas. Hal ini menimbulkan pertanyaan bagi peneliti sebagaimana tercantum dalam rumusan masalah dalam penelitian ini, yaitu (1) Bagaimana Tindakan Pemerintah Daerah dalam upaya mengatasi DAS Brantas? (2) Bagaimana kerjasama antara Pemerintah Daerah dan Masyarakat Desa Sumber Brantas dalam memelihara Sungai Brantas? (3) Bagaimana kehidupan sosial masyarakat Desa SumberBrantas dalam memelihara jenis Brantas? Jenis penelitiannya adalah penelitian kualitatif deskriptif (Description Research). Daerah penelitian dipilih secara purposif, di Desa Sumber Brantas, Kecamatan Bumiaji, Kota Batu. Penelitian ini menggunakan catatan lapangan dan wawancara mendalam antara informan yaitu Pemerintah Daerah dan masyarakat DAS Brantas. Data yang diperoleh akan dianalisis dengan menggunakan teknik deskriptif kualitatif dan data diperiksa validitasnya dengan triangulasi. Temuan hasil penelitian tersebut, kerja sama antara Pemerintah dan Masyarakat Desa Sumber Brantas masih belum optimal, karena partisipasi masyarakat masih lemah, hal ini membuat permasalahan yang terjadi di DAS Brantas berlarut-larut dalam penanganannya. Masyarakat desa SumberBrantas dikategorikan sebagai komunitas petani yang diketahui masih kental dengan kerjasama, dapat dilihat dalam kehidupan sehari-hari masyarakat sekaligus modal untuk meningkatkan pemahaman masyarakattentang pentingnya menjaga DAS Brantas.bersama.

Kata Kunci: Perencanaan Tata Ruang; Konservasi dan Pengelolaan Lingkungan; DAS Brantas. 
The increasing number of people, the lack of water absorption area and the increasing of settlement around the river flow, causing the river condition have decreasing in quality of water quality. Decrease in river water quality-quality is also caused by the pattern of community activities around the river. Damage and contamination of water among others occur as a result of the use of land uptake water that is used as are sidence to the disposal of residual house hold activities and industrial waste residue to oraround the river.

Batu City Local Government actually also hasa Regional Regulation (PERDA) No. 7 of 2011 on Spatial Planning for the Year 2010-2030 and Regional Regulation No 16 Year 2011 on Environmental Protection, Pengestolaian and Pengelolaian. On the other hand, Perum Perhutani has issued a partnership with the community, namely Joint Forest Management Society (PHBM). Joint Forest Management Community is a forest resource management system with a synergic collaboration between Perum Perhutani and forest village communities or stakeholders in an effort to achieve the sustainability of the functions and benefits of forester sources in the optimal Brantas Watershed area and the increase (Human Development Index) of HDI flexible, participatory and accommodative. PHBM is intended to provide a direction of forest resource management by integrating economic, ecological and social aspects in a proportional and professional manner. PHBM also aims to improve the roles and responsibilities of Perum Perhutani, forest village communities and stakeholders on the sustainability of the functions and benefits of forest resources, through the management of forest resources with a partnership model (Decree of the Perum Perhutani No: 268/KPTS/DIR/2007).

One of PHBM practices in Kota Batu is Socialization of Protection and Integrated Forest Protection (PPHT). But this program has not run optimally in the up watershed area 
Vol. 1 No.1 March2018

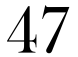

of Brantas, therefore the government and Perum Perhutani should be able to give special knowledge about the ecosystem network becoming the unity between forest and Berantas watershed. One of the obstacles of PHBM is the lack of community understanding, so that the community is not controlled in exploiting the forest freely, then this is exacerbated by the lack of knowledge related to environmental ecosystems.

The importance of maintaining the sustainability of the river with the current conditions that encourage researchers to know the continued efforts of local government in an effort to conserve the river Brantas. Both direct action and socialization to the community and cooperation aimed at Brantas watershed preservation.

\section{LITERATURE REVIEW}

\section{Contribution}

Cooperation is very important and necessary in human survival. Without cooperation there will be no family, no organization, especially there will be no process of activity in society (Lie, Lyngstadass et al. 2004). As quoted by Abdul syani, Roucek and Warren, said that cooperation means together to achieve common goals. It is one of the most basic social processes. Usually cooperation involves the division of tasks, where everyone does every job that is his responsibility for the achievement of common goals. As the case of states that cooperation is a form of social interaction in which the purpose of one group member is closely related to the purpose of the other group members or the group' sover all objectives so that an individual can only achieve the goal when another individual reaches aim (Nicholson 2005).

When this type of interaction develops among members of the Sumber Brantas Village community it can be expected that the community will help each other, support each other, give each other, depend on each other, and keep each other, 
especially to protect their environment Brantas waters hed. They will strive to coordinate and communicate with each other in order to avoid environmental damage. In general, this type of interaction is most prevalent in rural communities in Indonesia, because rural communities in Indonesia are culturally and historically having a mutual spirit of cooperation and cooperation.

\section{Concept of Social Capital}

Robert Putnam defines social capital as a social institution involving networks or networks, social norms and beliefs that encourage social collaboration for the common good. There is a need for a social bond (social network) that exist in society and norms that encourage community productivity. Putnam essentially sees social capital as covering social networks, social norms, and trust (Field 2010). Whereas According to Fukuyama social capital refers to informal norms that support the cooperation between individuals and capabilities arising from the prevalence of trust in a society or within certain parts of society. Social capital can facilitate economic expansion to a greater extent when supported by an expanding radius of trust (Ahmadi, Maany et al. 2003).

Social capital is always inseparable to the three basic elements of social capital which include (a) Belief (honesty, fairness, egalitarian attitudes, tolerance, and generosity);

(b) Social Network (participation, reciprocity, solidarity, cooperation);(c)Norms(shared values, norms and sanctions, rules). According to the three elements of social capital above and the following aspects are essentially the elements that exist or should exist in the life of a social group, whether the group is called community, community, ethnic groups, or other categories or in other words the elements of capital social is a lubricant that smoothed the machine structure of social structure well. 
Vol. 1 No.1 March2018

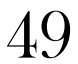

The concept of social capital offers the importance of a relationship. By building relationships with each other, and keeping them in order, each individual can work together to get things accomplished beforehand and to minimize great difficulties. Social capital determines how people can work together easily. The nature of social capital is the social relationship that exists in the daily life of the citizens. Social relationships reflect the results of social interaction in a relatively long time resulting in networks, patterns of cooperation, social exchange, mutual trust, including the values and norms that underlie such social relations (Ibrahim 2006).

\section{Role of Social Capital in Contribution}

Social capital can be described as the product of human relationships with each other, especially intimate and consistent relationships. Social capital refers to networks, norms and beliefs that have the potential for community productivity. However, social capital differs from financial capital, because social capital is cumulative and self-reinforcing (Putnam 1993). Therefore, social capital will not be exhauste difused, but increasingly, social capital also refers to the ability of people to associate with others (Coleman 1988). Relying on shared norms and values, the interfaith associations produce trust which in turn has a large and measurable economic value (Fukuyama 1995).

Social capital is a social relationship between human beings that can be used to achieve a goal orgain a profit, the development of social capital based on the concept of capital in the concept of capital in the beginning can be understood as the accumulation of the amount of money that can be invested in the hope of obtaining a favorable results dimsa will come (Field 2010). Social capital, just like anyother capital, can also be view deeded investment that can be used to make a profit. 
Social capital can be interpreted as an informal norm that can encourage the formation of a cooperation between individuals (Fukuyama 2002). In this definition, according to Fukuyama, trust, networks and community groups are the result of social capital and not the social capital itself. While norms referred to as social capital that can encourage the formation of cooperation such as honesty, keeping the commitment, the ability to perform tasks with reliable, reciprocal norms, and soon, Social capital is as any relationship that occurs and is bound by a trust, mutual understanding, and shared values that bind members of the group to make possible joint action can be done efficiently and effectively (Cohen and Prusak 2001).

\section{RESEARCH METHOD}

The type of research used by the authors in this study is descriptive qualitative research. This research focuses on observation and analysis of attitude and behavior of Sumber Brantas Village community. The type of descriptive research is a form of research aimed at describing the phenomena that exist, both natural phenomena and manmade phenomena.

In this research, the writer tries to collect data completely as a whole and integral to be able to give a clear picture of government action together with society related to Brantas watershed preservation.

In order to obtain more proven information, there a reseveral criteria that need to be considered, among others: (1) old and intensive subjects with an activity or activity targeted or research attention, (2) (3) Subjects with sufficient information, lots of time and opportunity to be questioned, (4) Subjects residing or staying on a treat menttar get who knows the incident (Faisal 1990). 
Vol. 1 No.1 March2018

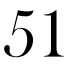

Criteria determined by the author in determining informants based on the above considerations, namely: (1) Work or activity in the environment of institutions that become the object of research, such as Perum Perhutani, RPH Batu (PHBM), Forestry and Agriculture Office Batu City, Batu City, Jasa Tirta Kota Malang and Sumber Brantas Village Community. (2) Working or doing activities within the Village Deviance Institution to find out programs that have been progressing from the government, (3) Understanding the social life of the Sumber Brantas Village Community.

To understand the amount of research data that has been obtained, it is necessary to do the processing of data that has been obtained. States that data analysis is the process of searching and compiling systematically data obtained from interviews, field notes, and other materials (Sugiyono 2010). Data analysis is done by organizing the data, spelling it into units, synthesizing, organizing into patterns, choosing what is important and learning, and making conclusions. Forward several important points to consider in conducting qualitative data analysis, among others: (1) Qualitative data analysis can be done simultaneously with data collection process, and other narrative writing. (2) make sure that the qualitative data analysis process has been performed based on the data reduction and interpretation process. (3) Change the data of the reduction product into matrix form. (4) Identification of coding procedures is used in reducing information into themes or categories.(5)The result of data analysis that has passed the reduction procedure that has been converted into a coded form of matrix, then adjusted to the qualitative model chosen (Herdiansyah 2010). 


\section{RESULT AND DISCUSSION}

\section{Community Development}

Watershed area is an integral area of ecosystem where humans including in it have double function, that is as part of Brantas watershed ecosystem component and function in the utilization of natural resources. Damage to Brantas Watershed can be caused by human activities and or by natural disasters. Therefore, in Brantas watershed management needs to involve the active participation of the community, so asto achieve maximum benefits and sustainable. Therefore, the target of fostering human activities in the utilization of natural resources includes:

1. Counseling/education and coaching to improve the perception and ability to manage the environment;

2. Reduce the rate of growth and population density; 3 .

Increase population income;

3. Creating jobs outside the agricultural sector

4. Improve public health through improved nutrition, improvement of health infrastructure

5. Developing non-governmental organizations

\section{Integrated Brantas River Basin Management}

Watershed management activities include 4 activities, including: (a) Forest management (vegetation), (b) Land management, (c) Water management, (d) Development of human activities in utilizing available natural resources.

\section{Forest Management}

Forests in Indonesia have a good role, in terms of economic, socio-cultural, and ecological. Forests have a variety of functions, among others, as a producer of wood, as a protective environment that functions to regulate the water system, protect soil fertility, and prevent erosion and others. However, in line with population growth and economic 
growth, technology for forest resources is increasing. To overcome this problem, it is necessary to do forest management strategy not only in terms of forest utilization, institutional, legal and regulatory aspects that support sustainable forest management efforts. In sustainable forest management, forest resources must be viewed from a new perspective not only as a resource that has a multipurpose but changing economic value, from tree management to ecosystem management. In principle, forest management must be maximally implemented based on the principle of sustainability. Forest management objectives are primarily intended to conserve forest functions (vegetation), (1) forest as a source of germplasm; (2) forest as a source of wood production; (3) forest as a hydro-orological function; (4) forest as water regulator, preventing and limiting flooding, erosion and; (5) forest as pollution control;

(6) protecting the climate and giving good effect; (7) provide natural beauty in general and in particular in the form of nature, wildlife sanctuary, labor garden and tourist park. Therefore, forest management objectives, among others:

(a) increase species diversity;(b) reforestation and afforestation on degraded lands; (c) selection of species to enhance the economic and ecological value of vegetation/plants;(d) regulation and improving logging techniques; (e) improving the production process of forest products.

\section{Land Management}

The increasing need for land for development needs has increased pressure on soil resources. In addition, the development of land resources also faces the problem of in compatibility between various interests and various economic sectors which in turn will be counterproductive with each other To overcome this problem, it is necessary to formulate a strategy in efficient, fair and sustainable land resource planning in order to prevent the negative impact of the activities undertaken. Land management aims to increase the 
productivity of land/land is high and coupled with the effort to maintain the quality of the land. DAS as a land system is basically capable of being used to meet various interests.

\section{Water Resources Management}

Water resources is a resource that felt more limited. In order to avoid this, water resources management strategies should be directed to the protection and conservation of water resources and to change peoples habits that assume water is an unlimited resource. In addition, in the management of water resources, it is necessary to carry out various measures that include the efficiency and the distribution of water resources as needed. Water management objectives in watershed management include; (1) maintaining water conservation (increasing water availability, reducing maximum and minimum flow rates, reducing sediment yields and improving water quality). (2) Managing the utilization of water resources for various purposes (drinking water, irrigation, industry, recreation, fisheries).

\section{CONCLUSION}

Brantas watershed management should be conducted jointly between the Local Government and the community, through a system that can provide: (1) High land productivity;

(2) Brantas Watershed Preservation ;(3)Increasing peoples welfare. Damage to natural resources and the environment in general due to human activities in the utilization of natural resources is not done arief by basing the method of conservation of natural resources; (4) Watershed management should be conducted in an integrated and coordinated manner, especially in community development; and (5) In the implementation of an integrated watershed management planning system with due attention to clarity of linkages between related sectors, at the local, regional and national levels. 


\section{REFERENCES}

Ahmadi, J., et al. (2003). "Treatment of intravenous buprenorphine dependence: a randomized open clinical trial." German Journal of Psychiatry 6(1): 23-29.

Cohen, D. J. and L. Prusak (2001). "In good company: How social capital makes organizations work." Ubiquity 2001(January): 3.

Coleman, J. S. (1988). "Social capital in the creation of human capital." American journal of sociology 94: S95-S120.

Faisal, S. (1990). Penelitian Kualitatif: Dasar-dasar dan aplikasi,YA3.

Field, J. (2010). "Modal sosial." Bandung: Kreasi Wacana.

Fukuyama, F. (1995). Trust: The social virtues and the creation of prosperity, Free Press Paperbacks.

Fukuyama, F. (2002). "Social capital and development: The coming agenda." SAIS review 22(1): 23-37.

Herdiansyah, H. (2010). Metodologi penelitian kualitatif untuk ilmu-ilmu sosial, Jakarta: Salemba Humanika.

Ibrahim, S. S. (2006). "From individual to collective capabilities: the capability approach as a conceptual framework for self-help." Journal of human development 7(3): 397-416.

Lie, R. T., et al. (2004). "Birth defects in children conceived by ICSI compared with children conceived by other IVF-methods; a metaanalysis." International journal of epidemiology 34(3): 696-701.

Nicholson, D. F. (2005). Environmental dispute resolution in Indonesia, Leiden University, Faculty of Law, Dept. of Metajuridica.

Putnam, R. D. (1993). "The prosperous community." The american prospect 4(13): 35-42.

Sugiyono, P. D. (2010). "Metode penelitian pendidikan." Pendekatan Kuantitatif. 